\title{
Expansão, privatização e diferenciação da educação superior no Brasil pós - LDBEN/96: evidências e tendências
}

\author{
Stella Cecilia Duarte Segenreich \\ Antonio Mauricio Castanheira**
}

\section{Resumo}

A proposta do presente trabalho é, com base nos Censos da Educação Superior de 1996 a 2006, aprofundar questões relativas à privatização e à diferenciação do sistema brasileiro de educação superior, no contexto de sua expansão, explorando as categorias referentes a instituições, cursos e corpo discente. A análise assumiu como marco divisório o Plano Nacional de Educação de 2001, que vem servindo de parâmetro para as tendências de evolução do sistema. Verificou-se que as políticas públicas de expansão para este nível de ensino estão tendendo a enfatizar a diferenciação do sistema com ênfase na esfera pública, seja por meio de novos tipos de curso/instituições - cursos superiores de tecnologia nos Institutos Federais de Educação, Ciência e Tecnologia, - seja pela institucionalização da educação a distância pela Universidade Aberta do Brasil. 0 processo de privatização continua, menos acelerado, sob outras formas tais como a concessão de bolsas do MEC para o ProUni.

Palavras-chave: Educação superior. Expansão da educação superior. Diferenciação. Privatização.

\section{Expansion, privatizacion and differences in higher education in Brazil pos - LDBEN/96: evidences and tendencies.}

\section{Abstract}

This paper has the purpose of exploring the categories which refer to institutions, courses and student body, aiming at making a study of issues related to privatization and to this system differentiation, in the context of its expansion. It is based on the Brazilian Higher Education Census from 1996 to 2006. The Education National Plan (2001) was considered as a boundary

* Doutora em Educação pela UFRJ; Professora do Mestrado em Educação da Universidade Católica de Petrópolis. E-mail: stella.segen@terra.com.br

** Doutor em Filosofia pela UFRJ; Professor do Mestrado em Educação da Universidade Católica de Petrópolis e do CEFET/RJ. Email:maurício.castanheira@gmail.com 
mark, as it has been used as a parameter when evaluating the evolution tendencies of the system. It was possible to verify that public choices to expand such educational level have tended to emphasize the system differentiation, with an emphasis on public sphere, by means of either new types of courses/institutions - Higher Education courses on Technology at the Federal Institutions of Education, Science and Technology - or the institutionalization of Distance Education - Brazilian Open University. The privatization process goes on, not so fast, through other ways like the concession of scholarships to the ProUni.

Keywords: Higher Education. Higher Education expansion. Differentiation. Privatization.

\section{Expansión, privatización y diferenciación de la educación de nivel superior en Brasil pos - LDBEN/96: evidencias y tendencias. Resumen}

La propuesta del presente trabajo es, con base en los Censos de la Educación Superior de 1996 a 2006, profundizar cuestiones relativas a la privatización y a la diferenciación del sistema brasileño de educación superior, en el contexto de su expansión. El análisis asumió como marco divisorio el Plan Nacional de Educación de 2001, que viene sirviendo de parámetro para las tendencias de evolución del sistema. Se identificó que las políticas públicas de expansión para este nivel de enseñanza han inclinado para resaltar la diferenciación del sistema con énfasis en la esfera pública, sea por medio de nuevos tipos de curso/ instituciones - cursos superiores de tecnología en los Institutos Federales de Educación, Ciencia y Tecnología - sea por la institucionalización de la educación a distancia en las universidades federales - Universidade Aberta de Brasil. El proceso de privatización sigue, menos acelerado y bajo otras formas, tales como, la concesión de becas del MEC para el ProUni.

Palabras clave: Educación superior. Expansión de la educación superior. Diferenciación. Privatización.

\section{Introdução}

Em 2006, o Instituto Nacional de estudos e Pesquisas Educacionais Anísio Teixeira (INEP) publicou uma coleção (RISTOFF; GIOLO, 2006) na qual apresentava, pela primeira vez, a série de dados do Censo da Educação Superior relativa ao período 1991-2004, acompanhada de uma análise, por estado da Federação, do comportamento da educação superior nesse periodo, feita por pesquisadores ligados ao GT de Política de Educação Superior da Associação Nacional de Pesquisa e Pós-Graduação em Educação (ANPEd). Os dados foram analisados levando em consideração

Ensaio: aval. pol. públ. Educ., Rio de Janeiro, v. 17, n. 62, p. 55-86, jan./mar. 2009 
Expansão, privatização e diferenciação da educação superior

dois subperíodos, 1991-1996 e 1996-2004, tomando como marco divisório a promulgação da Lei de Diretrizes e Bases da Educação Nacional (LDBEN), Lei $n^{0}$ 9.394, de 20 de dezembro de 1996 (BRASIL, 1996).

0 roteiro seguido incluiu os seguintes indicadores: número de instituições e de cursos; vagas oferecidas; candidatos inscritos ; ingressantes; matrícula; concluintes; funções docentes; e funcionários técnico-administrativos. A tabela 1 apresenta os dados numéricos desses indicadores.

Tabela 1- Evolução numérica do ensino superior e percentuais de crescimento Brasil, 1991 a 2004.

\begin{tabular}{l|r|r|r|r|r}
\hline & & & & $\Delta \%$ & $\Delta \%$ \\
\hline Temas & 1991 & 1996 & 2004 & $\begin{array}{r}1991 \\
-1996\end{array}$ & $\begin{array}{r}1996 \\
-2004\end{array}$ \\
\hline Instituições & 893 & 922 & 2.013 & 3,2 & 118,3 \\
\hline Cursos & 4.908 & 6.644 & 18.644 & 35,4 & 180,6 \\
\hline Vagas oferecidas & 516.663 & 634.236 & 2.320 .421 & 22,8 & 265,9 \\
- cursos presenciais & 1.985 .825 & 2.548 .077 & 5.053 .992 & 28,3 & 98,3 \\
\hline Candidatos inscritos & 426.558 & 513.842 & 1.303 .110 & 20,5 & 153,6 \\
\hline Ingressantes & 1.565 .056 & 1.868 .529 & 4.163 .733 & 19,4 & 122,8 \\
\hline Matricula & 236.410 & 260.224 & 626.617 & 10,1 & 140,8 \\
\hline Concluintes & 146.988 & 164.118 & 293.242 & 11,7 & 78,7 \\
\hline Funções docentes & 184.928 & 222.202 & 260.642 & 20,2 & 17,3 \\
\hline Funcionários & & & & & \\
técnico-administrativos & & & & & \\
\hline
\end{tabular}

Fonte: Segenreich e outros (2006).

Uma primeira evidência, facilmente constatável, é a de que todos os índices de crescimento apresentam valor positivo, havendo um aumento significativo desses indices no periodo que se segue à promulgação da LDBEN (BRASIL, 1996). Essa expansão, no período 1996-2004, não se deu de forma homogênea. Na Tabela 1 pode-se verificar, por exemplo, que o índice de crescimento de vagas oferecidas ultrapassou, em muito o índice de crescimento de candidatos inscritos. Mas essas diferenças vão bem mais longe quando se desce à análise de subcategorias como esfera administrativa ou organização acadêmica, como pôde ser constatado nas análises feitas por estado da Federação.

Em relação á categoria esfera administrativa, uma das conclusões mais evidenciadas pelos dados analisados no Estado do Rio de Janeiro (SEGENREICH et al., 2006), por exemplo, se refere ao aprofundamento da privatização da educação 
superior, principalmente no período 1996-2004. No que diz respeito à organização acadêmica e oferta de cursos, o processo de diferenciação das instituições e modalidades de ensino iniciado a partir da LDBEN (BRASIL, 1996), está trazendo novos atores para o processo de expansão da educação superior, questão cuja análise merece ser aprofundada.

A proposta do presente trabalho é explorar, em âmbito nacional, as categorias referentes a instituições, cursos e estatísticas referentes ao corpo discente (vagas oferecidas, candidatos, ingressantes, matriculados e concluintes) com o objetivo de, mediante a atualização da série histórica para abranger o período 1996 - 2006 (INEP, 1999, 2002, 2007), aprofundar a análise das questões relativas à privatização e diferenciação do sistema de educação superior, já apontadas no estudo anterior, e identificar novas tendências que estão surgindo. Foi também adotado um novo marco divisório nesse período: o Plano Nacional de Educação (PNE), de 2001. As metas estabelecidas pelo PNE (BRASIL, 2001) têm sido constantemente mencionadas para justificar as políticas públicas para educação superior adotadas no período 2001-2006 e continuam a servir de parâmetro para as tendências de evolução do sistema, que serão aqui apontadas.

A presença das esferas pública e privada na expansão da educação superior

No panorama da educação superior no Brasil, apresentado por Ristoff e Giolo (2006), expansão e privatização aparecem intimamente relacionadas. Segundo esses autores, é no período pós-LDBEN (1996-2004) que se evidencia o enquadramento do sistema educacional às regras do mercado, com a busca crescente da classe média baixa e de alguns setores populares pelo acesso à educação superior. Eles concluem:

\begin{abstract}
Essa demanda era o que faltava para que a iniciativa privada vislumbrasse, na educação, uma excelente oportunidade de negócio. Instituições com fins lucrativos, ágeis e competitivas, disseminaram-se pelos quadrantes do Brasil, obrigando toda a rede privada a se mobilizar na mesma direção. [...] A política educacional sentia-se plenamente justificada com a resposta dada pela iniciativa privada na oferta da educação superior, de modo que não viam razões para expandir a rede pública. Com efeito, as instituições do sistema federal receberam pouca atenção e pouco investimento, por isso seu relativo encolhimento no conjunto do sistema (RISTOFF; GIOLO, 2006, p. 20).
\end{abstract}

0 que merece ser aprofundado nesta questão não é a existência ou não de um processo de privatização, fato já evidenciado em vários estudos (SGUISSARDI, 2004; MANCEBO, 2004; CARVALHO, 2006), mas em que aspectos - instituições, cursos e dados relativos ao corpo discente - essa privatização se mostrou mais presente, e que consequências trouxe para o sistema de educação superior.

Ensaio: aval. pol. públ. Educ., Rio de Janeiro, v. 17, n. 62, p. 55-86, jan./mar. 2009 


\section{Instituições}

0 Censo da Educação Superior de 2006 (INEP, 2007) registrou a existência no Brasil de 2.270 instituições de educação superior (IES) que, no período da coleta de dados, tinham, pelo menos, um curso em funcionamento'. Isto implica um crescimento de 146,2 \% em 10 anos.

Analisando o crescimento das IES por categoria administrativa - público $\mathrm{x}$ privado - começam a se delinear os primeiros caminhos trilhados pela expansão do ensino superior. A Tabela 2 e o Gráfico 1 permitem ratificar algumas evidências já constatadas no estudo promovido pelo INEP.

Tabela 2 - Número de IES por esfera administrativa (pública e privada) - Brasil, 1996 a 2006.

\begin{tabular}{l|r|r|r|r|r}
\hline Ano & \multicolumn{1}{|c|}{ Brasil } & \multicolumn{2}{|c|}{ Pública } & \multicolumn{2}{c}{ Privada } \\
\hline & & Total & $\%$ & Total & $\%$ \\
\hline 1996 & 922 & 211 & 27,9 & 711 & 77,1 \\
\hline 2001 & 1.391 & 183 & 13,2 & 1.208 & 86,8 \\
\hline 2006 & 2.270 & 248 & 10,9 & 2.022 & 89,1 \\
\hline $1996 / 2001 \Delta \%$ & 50,9 & $-14,3$ & - & 69,9 & - \\
\hline $2001 / 2006 \Delta \%$ & 63,2 & 35,5 & - & 67,4 & - \\
\hline $1996 / 2006 \Delta \%$ & 146,2 & 17,5 & - & 84,4 & - \\
\hline
\end{tabular}

Fonte: INEP (1999, 2002, 2007).

Na Tabela 2 fica evidente o período crítico de retração do setor público (14,3 de percentual de crescimento) em contraste com a expansão de 69,9 por cento de IES de iniciativa privada. Há uma recuperação do setor público no período 2001-2006 e um pequeno decréscimo de percentual de crescimento no setor privado, o que não impede uma contrastante diferença de percentual de crescimento entre os dois setores, no período visto como um todo: 17,5 para o setor público frente a 84,4 do setor privado. 0 Gráfico 1 permite visualizar com clareza esta comparação.

1 Importa registrar que o número de instituições independe do tamanho das mesmas, do número de estudantes que atendem ou do número de cursos de graduação e pós-graduação que oferecem.

Ensaio: aval. pol. públ. Educ., Rio de Janeiro, v. 17, n. 62, p. 55-86, jan./mar. 2009 


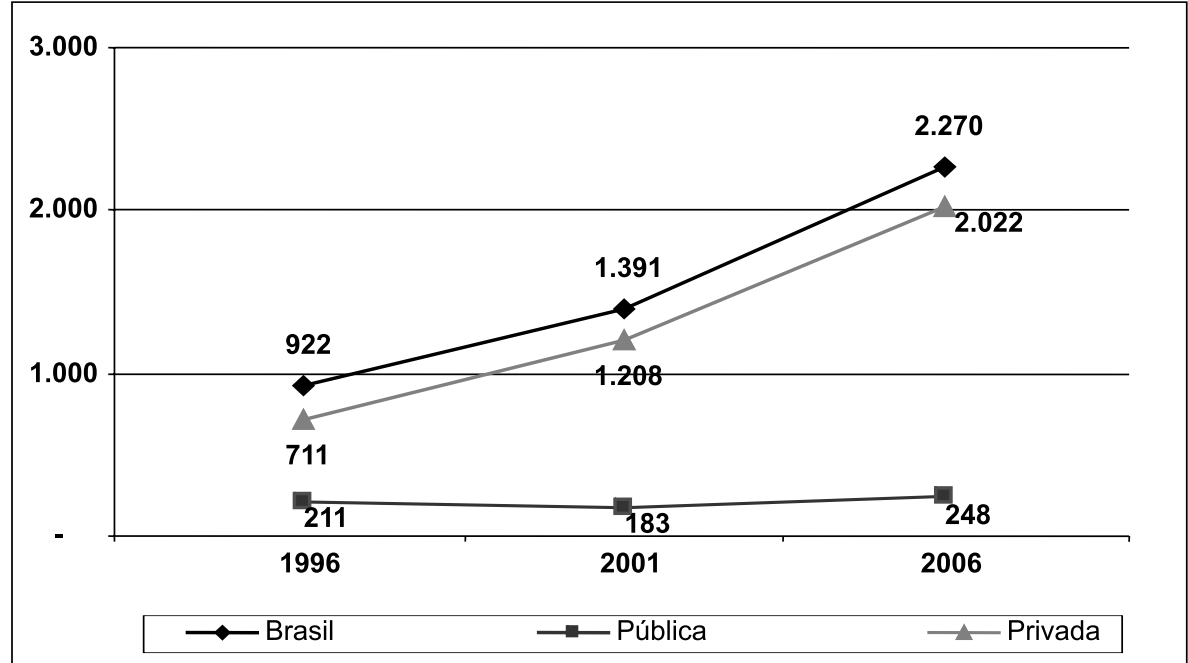

Gráfico 1 - Evolução do número de IES por categoria administrativa (pública e privada) - Brasil, 1991 a 2006.

Fonte: INEP (1999, 2002, 2007).

0 crescimento do setor público no segundo período se deve, em boa parte, à criação dos Centros de Educação Tecnológica, em relação estreita, pois, com a categoria diferenciação que será abordada em sequência. Entretanto, existe um processo de diferenciação, em termos de esfera administrativa, que não pode deixar de ser mencionado nesse momento. Trata-se da diferenciação de IES da rede privada em dois subgrupos de esfera administrativa ${ }^{2}$, estabelecida nas estatisticas do INEP a partir de 1997: a) instituições privadas particulares, que se apresentam como organizações com fins lucrativos; e b) instituições privadas confessionais, comunitárias e/ou filantrópicas, que se declaram sem fins lucrativos. Registramos, nesse momento, o fato de que no ano em que esta diferenciação foi estabelecida existiam 382 instituições privadas particulares e 307 instituições classificadas como privadas comunitárias, confessionais ou filantrópicas.

\section{Cursos}

0 Censo da Educação Superior de 2006 registrou a existência de 22.101 cursos de graduação presenciais no Brasil; em 1996 existiam 6.644. As estatísticas indicam um crescimento bastante alto dos cursos, cerca de $232,6 \%$ no período 1996-2006.

Introduzindo a categoria esfera administrativa e dividindo os dados por subperíodos, a Tabela 3 permite analisar como se comporta a distribuição dos cursos no Brasil, no período enfocado.

2 Até 1996 "particular" vigorava como categoria única.

Ensaio: aval. pol. públ. Educ., Rio de Janeiro, v. 17, n. 62, p. 55-86, jan./mar. 2009 
Expansão, privatização e diferenciação da educação superior

Tabela 3 - Distribuição percentual e taxa de crescimento do número de cursos de graduação presenciais por categoria administrativa (pública e privada) - Brasil, 1996 a 2006.

\begin{tabular}{l|r|r|r|r|r}
\hline \multirow{2}{*}{ Ano } & \multicolumn{1}{|c|}{ Brasil } & \multicolumn{2}{|c|}{ Pública } & \multicolumn{2}{c}{ Privada } \\
\hline & & Total & $\%$ & Total & $\%$ \\
\hline 1996 & 6.644 & 2.978 & 44,8 & 3.666 & 55,2 \\
\hline 2001 & 12.155 & 4.401 & 36,2 & 7.754 & 63,8 \\
\hline 2006 & 22.101 & 6.549 & 29,6 & 15.552 & 70,4 \\
\hline $1996 / 2001 \Delta \%$ & 82,9 & 47,8 & - & 111,5 & - \\
\hline $2001 / 2006 \Delta \%$ & 81,8 & 48,8 & - & 100,6 & - \\
\hline $1996 / 2006 \Delta \%$ & 232,6 & 120,0 & - & 324,2 & - \\
\hline
\end{tabular}

Fonte: INEP (1999, 2002, 2007).

Discriminando por categoria administrativa o percentual de $232,6 \%$ de crescimento dos cursos no Brasil, no periodo 1996-2006, pode-se verificar que o setor privado é responsável por um percentual de $324,2 \%$ de crescimento, enquanto o setor público cresceu somente 120,0\%. Entretanto, apesar de o ritmo de crescimento do setor privado ser mais alto no período como um todo, nota-se um pequeno decréscimo no percentual de crescimento do setor privado no segundo período e um ligeiro acréscimo do setor público no mesmo período. Até que ponto essas mudanças de direção significam novas tendências será objeto de análise ao final deste artigo.

Focalizando agora a participação percentual de cada categoria administrativa, por ano, verifica-se que a participação do setor público no total de cursos de graduação presenciais caiu de 44,8 \%, em 1996, para 29,6 \% em 2006. Esses dados, apresentados no Gráfico 3, permitem perceber a crescente privatização do ensino superior no Brasil, o que poderá ser confrontado, com a análise do comportamento das matrículas.

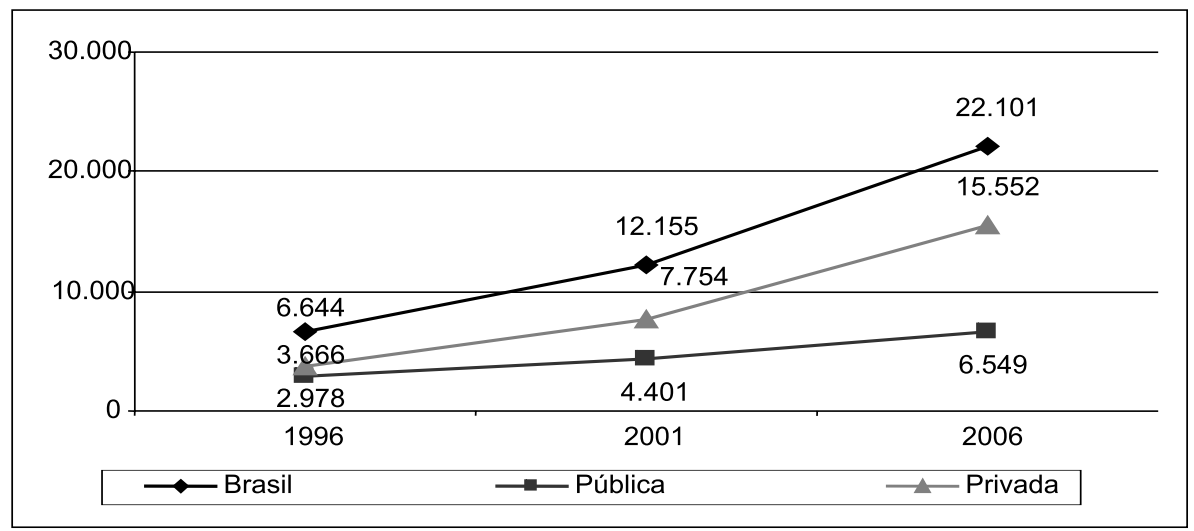

Gráfico 2 - Evolução do número de cursos de graduação presenciais, por categoria administrativa (pública e privada) - Brasil, 1996 a 2006.

Fonte: INEP (1999, 2002, 2007).

Ensaio: aval. pol. públ. Educ., Rio de Janeiro, v. 17, n. 62, p. 55-86, jan./mar. 2009 


\section{Matrículas}

0 Censo de 2006 registrou um total de cerca de três milhões e meio de matrículas nos cursos de graduação presenciais no Brasil. A análise da evolução das matrículas nos dez anos analisados (1996 a 2006) mostra, na Tabela 4, que a média nacional de crescimento foi de 150,3\%.

Tabela 4 - Percentual de crescimento de matrículas dos cursos de graduação presenciais por categoria administrativa (pública e privada) - Brasil, 1991 - 2006.

\begin{tabular}{l|r|r|r|r|r}
\hline Ano & \multicolumn{1}{|c|}{ Brasil } & \multicolumn{2}{|c|}{ Pública } & \multicolumn{2}{c}{ Privada } \\
\hline & & Total & $\%$ & Total & $\%$ \\
\hline 1996 & 1.868 .529 & 735.427 & 39,4 & 1.133 .102 & 60,6 \\
\hline 2001 & 3.030 .754 & 939.225 & 31,0 & 2.091 .529 & 69,0 \\
\hline 2006 & 4.676 .646 & 1.209 .304 & 25,9 & 3.467 .342 & 74,1 \\
\hline $1996 / 2001 \Delta \%$ & 62,2 & 27,7 & - & 84,6 & - \\
\hline $2001 / 2006 \Delta \%$ & 54,3 & 28,8 & - & 65,8 & - \\
\hline $1996 / 2006 \Delta \%$ & 150,3 & 64,4 & - & 206,0 & - \\
\hline
\end{tabular}

Fonte: INEP (1999, 2002, 2007).

Quando se analisa o comportamento das matrículas por categoria administrativa , percebe-se que, a exemplo do que acontece com as categorias instituições e cursos, o percentual de crescimento das matrículas nas instituições privadas $(206,0 \%)$ é bem mais alto do que o verificado nas instituições públicas (64,4\%). Entretanto, uma visão comparativa dos periodos analisados mostra a mesma tendência de queda no percentual de crescimento das matrículas em IES privadas (de 84,6 para $65,8 \%$ ) e uma pequena recuperação no ritmo de crescimento das matrículas nas IES públicas (de 27,7 para $28,8 \%$ ). No entanto, a ocupação de espaço do setor privado continua bastante alto: $74,1 \%$ das matrículas, nos cursos de graduação presencial, no ano de 2006. 0 Gráfico 3 permite visualizar a trajetória de crescimento das matrículas, no geral e por categoria administrativa. 
Expansão, privatização e diferenciação da educação superior

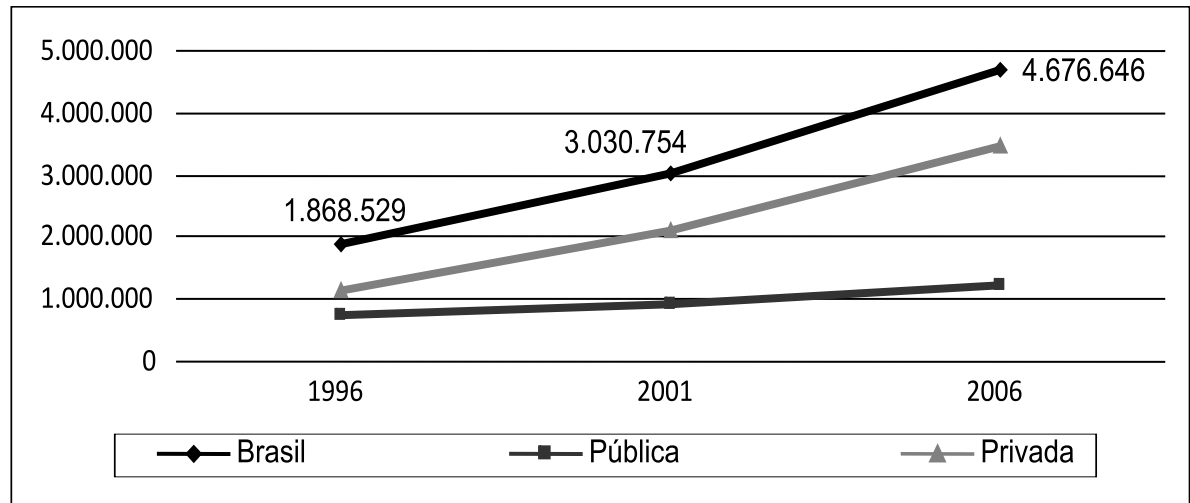

Gráfico 3 - Evolução do número de matrículas dos cursos de graduação presenciais - Brasil, 1991 a 2006.

Fonte: INEP (1999, 2002, 2007).

\section{Vagas, inscritos, ingressos e concluintes}

Os dados sobre vagas, ingressos e concluintes foram trabalhados individualmente e por meio da relação entre vagas oferecidas e ingressos com o objetivo de diagnosticar a existência de vagas ociosas no sistema de educação superior. Uma visão geral dos dados de crescimento dessas variáveis e suas respectivas variações percentuais de crescimento, nos dois subperíodos, é apresentada na Tabela 5.

Tabela 5 - Número e percentual de crescimento de vagas, inscritos, ingressantes e concluintes dos cursos de graduação presenciais - Brasil, de 1996 a 2006.

\begin{tabular}{l|r|r|r|r}
\hline Ano & Vagas & Inscritos & Ingressos & Concluintes \\
\hline 1996 & 634.236 & 2.548 .077 & 513.842 & 260.224 \\
\hline 2001 & 1.408 .492 & 4.260 .261 & 1.036 .690 & 395.988 \\
\hline 2006 & 2.629 .598 & 5.181 .699 & 1.448 .509 & 736.829 \\
\hline $1996 / 2001 \Delta \%$ & 122,1 & 67,2 & 101,8 & 52,2 \\
\hline $2001 / 2006 \Delta \%$ & 86,7 & 21,6 & 39,7 & 86,1 \\
\hline $1996 / 2006 \Delta \%$ & 314,6 & 103,4 & 181,9 & 183,2 \\
\hline
\end{tabular}

Fonte: INEP (1999, 2002, 2007).

Analisando-se o período como um todo, constata-se que as taxas de crescimento são positivas mas chama atenção o fato de que o maior percentual de crescimento seja o de vagas $(314,6 \%)$ enquanto que o número de inscritos apresenta o menor percentual $(103,4 \%)$. Comparando os percentuais por subpe- 
ríodo, é possivel também constatar que todas as variáveis discentes de entrada no ensino superior tiveram uma queda no percentual de crescimento, o que levanta questões sobre o porquê da queda do ritmo de expansão do ensino de graduação presencial e suas possíveis implicações. Uma das possiveis causas dessa "queda", que tem sido objeto de debate, refere-se à incapacidade de parte da população de arcar com o financiamento de sua educação superior nas IES privadas. Um outro dado pode ajudar nesse raciocínio: a análise da relação entre vagas oferecidas e ingressos, chegando ao cálculo das vagas ociosas no sistema.

Para isso foi montada, em um primeiro momento, a Tabela 6, com as estatísticas de crescimento de vagas oferecidas e ingressos por categoria administrativa para, em seguida, apresentar a evolução do número de vagas ociosas existentes no sistema, no período 1996-2006. Nessa tabela já é possível constatar as significativas diferenças de percentual de crescimento tanto de vagas oferecidas como de ingressos entre a rede pública e a rede privada de ensino superior.

Tabela 6 - Número e crescimento percentual de vagas oferecidas e ingressos nos cursos de graduação presenciais por categoria administrativa (pública e privada) Brasil, 1996 a 2006.

\begin{tabular}{|c|c|c|c|c|c|c|c|c|c|c|}
\hline \multirow{3}{*}{ Ano } & \multicolumn{5}{|c|}{$\begin{array}{l}\text { Vagas nos Cursos de } \\
\text { Graduação Presenciais }\end{array}$} & \multicolumn{5}{|c|}{$\begin{array}{l}\text { Ingressos nos Cursos de } \\
\text { Graduação Presenciais }\end{array}$} \\
\hline & \multirow{2}{*}{ Brasil } & \multicolumn{2}{|c|}{ Pública } & \multicolumn{2}{|c|}{ Privada } & \multirow{2}{*}{ Brasil } & \multicolumn{2}{|c|}{ Pública } & \multicolumn{2}{|l|}{ Privada } \\
\hline & & Total & $\%$ & Total & $\%$ & & Total & $\%$ & Total & $\%$ \\
\hline 1996 & 634.236 & 183.513 & 29 & 450.723 & 71 & 513.842 & 166.494 & & 347.348 & \\
\hline 2001 & 1.408 .492 & 256.498 & 18 & 1.151 .994 & 82 & 1.036 .690 & 244.621 & & 792.069 & \\
\hline 2006 & 2.629 .598 & 331.105 & 13 & 2.298 .493 & 87 & 1.448 .509 & 297.407 & & 1.151 .102 & \\
\hline $1996 / 2001 \Delta \%$ & 122,1 & 39,8 & - & 155,6 & - & 101,8 & 46,9 & - & 118,0 & - \\
\hline $2001 / 2006 \Delta \%$ & 86,7 & 29,1 & - & 99,5 & - & 39,7 & 21,6 & - & 45,3 & - \\
\hline $1996 / 2006 \Delta \%$ & 314,6 & 80,4 & - & 410,0 & - & 181,9 & 78,6 & - & 231,4 & - \\
\hline
\end{tabular}

Fonte: INEP (1999, 2002, 2007).

A partir da constatação de que o percentual de crescimento de ingressos e, principalmente, de vagas na rede privada é bem maior do que na rede pública, procurou-se calcular o número de vagas ociosas no período, por categoria administrativa. 0 resultado consta da Tabela 7. 
Expansão, privatização e diferenciação da educação superior

Tabela 7 -Número e crescimento percentual de vagas ociosas nos cursos de graduação presenciais por categoria administrativa (pública e privada) - Brasil, 1996 a 2006.

\begin{tabular}{|c|c|c|c|c|c|}
\hline \multirow{2}{*}{ Ano } & \multirow{2}{*}{ Brasil ${ }^{*}$} & \multicolumn{2}{|l|}{ Pública } & \multicolumn{2}{|l|}{ Privada } \\
\hline & & Total $^{*}$ & $\%$ & Total* & $\%$ \\
\hline 1996 & 120.394 & 17.019 & 14,1 & 103.375 & 85,9 \\
\hline 2001 & 371.802 & 11.877 & 3,2 & 359.925 & 96,8 \\
\hline 2006 & 1.181 .089 & 33.698 & 2,9 & 1.147.391 & 97,1 \\
\hline $1996 / 2001 \Delta \%$ & 208,8 & $-30,2$ & - & 248,2 & - \\
\hline $2001 / 2006 \Delta \%$ & 217,7 & 183,7 & - & 218,8 & - \\
\hline $1996 / 2006 \Delta \%$ & 881,0 & 98,0 & - & $1.009,9$ & - \\
\hline
\end{tabular}

* Vagas menos ingressos

Fonte: INEP (1999, 2002, 2007).

Os dados apresentados na Tabela 7 comprovam o aumento vertiginoso do número de vagas ociosas na rede privada, nos dois subperiodos analisados: 248,2\% de 1996 a 2001 e $218,8 \%$ de 2001 a 2006. Esse quadro já se vinha tornando visivel em estudos anteriores (SEGENREICH et al., 2006); logo, não é de se admirar a urgência da criação de um socorro à eminência de um colapso na rede privada, representado pela criação do Programa Universidade para Todos (ProUni), em 2004. Esta política pública foi denunciada por vários autores como mais um passo para a privatização do ensino superior com recursos públicos (OTRANTO, 2006; CATANI; HEY; GILIOLI, 2006; CARVALHO, 2006).

0 Gráfico 4 confirma visualmente esta constatação.

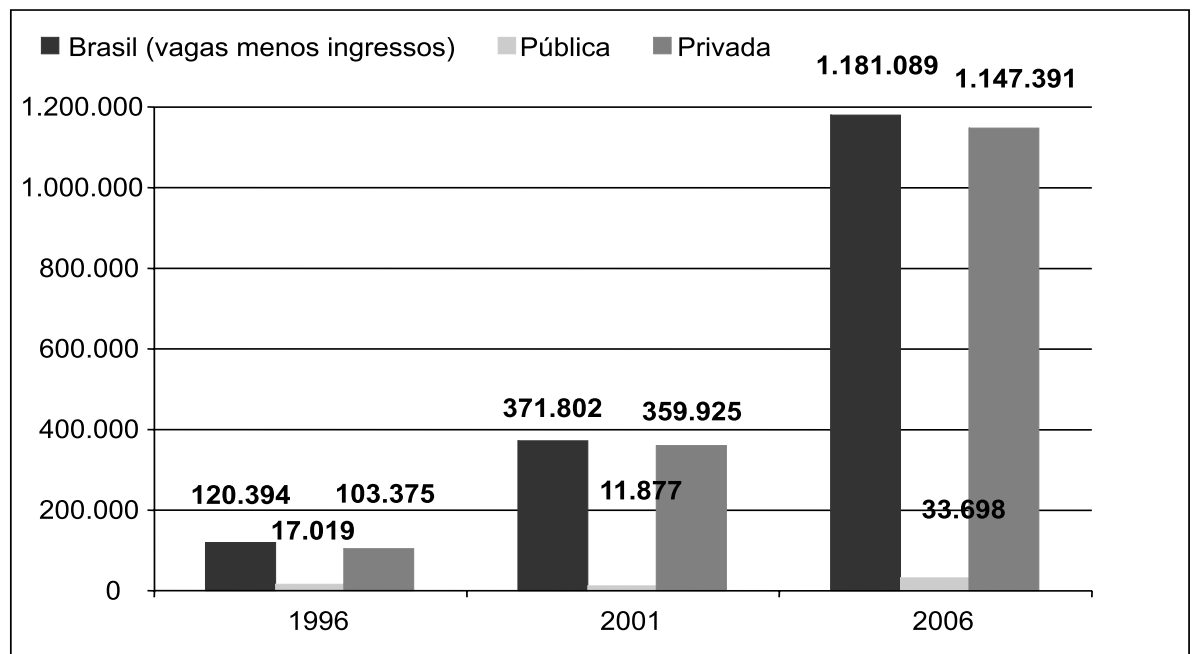

Gráfico 4 - Número e crescimento percentual de vagas ociosas nos cursos de graduação presenciais por categoria administrativa (pública e privada) - Brasil, 1996 a 2006. Fonte: INEP (1999, 2002, 2007). 


\section{A influência do processo de diferenciação de tipos de IES na expansão da educação superior}

Basicamente, a diferenciação no sistema de educação superior se manifestou em três aspectos: novas formas de organização institucional, novos tipos de curso e nova modalidade de ensino. Nesse momento serão enfocadas as novas formas de organização institucionalizadas pela LDBEN (BRASIL, 1996).

Na Tabela 8 e no Gráfico 5, que apresentam a distribuição das IES segundo organização acadêmica, estão representados todos os tipos de IES que integram o atual sistema de Educação Superior.

Tabela 8 - Distribuição percentual e taxa de crescimento do número de IES por organização acadêmica - Brasil, 1996 a 2006.

\begin{tabular}{|c|c|c|c|c|c|c|}
\hline \multirow[b]{2}{*}{ Ano } & \multirow[b]{2}{*}{ Brasil } & \multicolumn{5}{|c|}{ Organização Acadêmica } \\
\hline & & $\begin{array}{l}\text { Univer- } \\
\text { sidades }\end{array}$ & $\begin{array}{l}\text { Centros } \\
\text { Univer- } \\
\text { sitários }\end{array}$ & $\begin{array}{l}\text { Faculdades } \\
\text { Integradas }\end{array}$ & $\begin{array}{c}\text { Faculdades, } \\
\text { Escolas, } \\
\text { Institutos }\end{array}$ & $\begin{array}{l}\text { Centros de } \\
\text { Educação } \\
\text { Tecnológica } \\
\text { e Faculdades } \\
\text { de Tecnologia }\end{array}$ \\
\hline 1996 & 922 & 136 & -- & 143 & 643 & - \\
\hline 2001 & 1.391 & 156 & 66 & 99 & 1.036 & 34 \\
\hline 2006 & 2.270 & 178 & 119 & 116 & 1649 & 208 \\
\hline $1996 / 2001 \Delta \%$ & 39,1 & 14,7 & - & $-31,8$ & 61,1 & - \\
\hline $2001 / 2006 \Delta \%$ & 63,2 & 14,1 & 80,3 & 17,2 & 59,2 & 511,8 \\
\hline $1996 / 2006 \Delta \%$ & 146,2 & 30,9 & - & $-19,9$ & 156,5 & - \\
\hline
\end{tabular}

Fonte: INEP (1999, 2002, 2007).

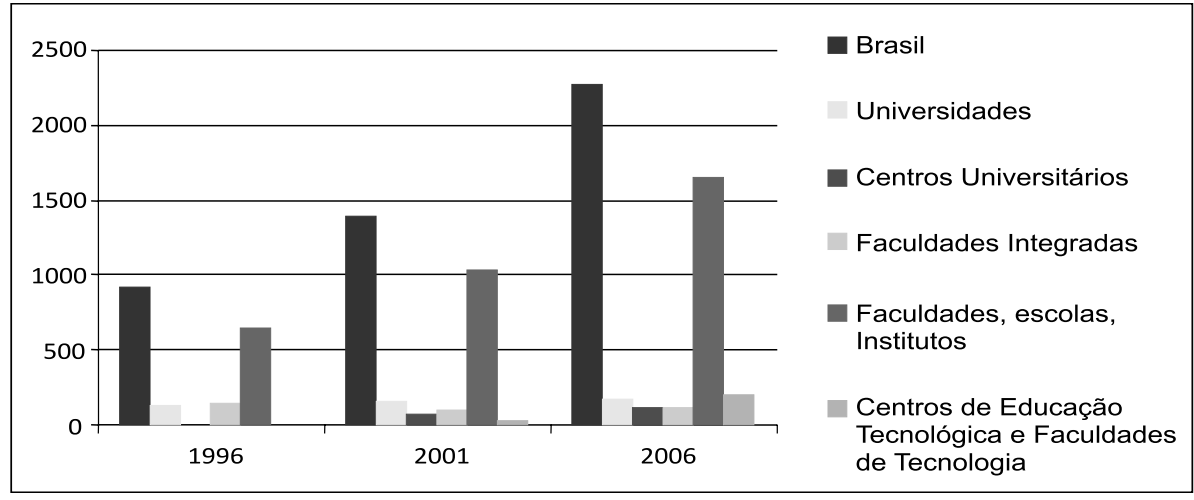

Gráfico 5 - Número de IES por organização acadêmica - Brasil, 1996 a 2006. Fonte: INEP (1999, 2002, 2007).

Ensaio: aval. pol. públ. Educ., Rio de Janeiro, v. 17, n. 62, p. 55-86, jan./mar. 2009 
Analisando o índice de crescimento de cada tipo de IES, pode-se perceber que somente as faculdades integradas apresentam acentuado índice negativo de crescimento $(-31,8 \%)$ no periodo $1996-2001$ enquanto as faculdades isoladas crescem $61,1 \%$. 0 movimento de migração das IES de uma categoria de organização acadêmica é representado, em parte, pelo processo de evolução de algumas dessas faculdades integradas até se transformarem em universidades.

Entretanto, a criação de universidades não foi o único destino de migração das faculdades integradas e/ou isoladas. Na Tabela 8, pode-se verificar ainda o aparecimento de três novas formas de IES, criadas em função da diversificação do sistema de educação superior. Como se sabe, dentre outras medidas, a LDBEN/ 1996 (BRASIL, 1996) flexibilizou as formas organizacionais de oferta de educação superior, possibilitando a criação de Centros Universitários, a partir de 1997, e de Centros de Educação Tecnológica e Faculdades de Tecnologia, a partir de 1999. Estas IES tiveram, no periodo 2001-2006, um crescimento percentual maior que as demais IES. Agregando as instituições tradicionais para compará-las com o conjunto de novas instituições, foram montados a Tabela 9 e o Gráfico 6, a seguir.

Tabela 9 - Distribuição percentual e taxa de crescimento do número de IES préLDBEN/96 e pós-LDBEN/96 - Brasil, 1996 a 2006.

\begin{tabular}{l|c|c|c}
\hline Ano & Brasil & IES Pré/LDBEN* & IES Pós/LDBEN** \\
\hline 1996 & 922 & 922 & ---- \\
\hline 2001 & 1.391 & 1.291 & 100 \\
\hline 2006 & 2.270 & 1.943 & 327 \\
\hline $1996 / 2001 \Delta \%$ & 39,1 & 40,0 & -- \\
\hline $2001 / 2006 \Delta \%$ & 63,2 & 50,5 & 227,0 \\
\hline $1996 / 2006 \Delta \%$ & 146,2 & 110,7 & -- \\
\hline
\end{tabular}

* Universidades, Faculdades Integradas, Faculdades, Escolas, Institutos

** Centros Universitários, Centros de Educação Tecnológica e Faculdades de Tecnologia

Fonte: INEP (1999, 2002, 2007). 


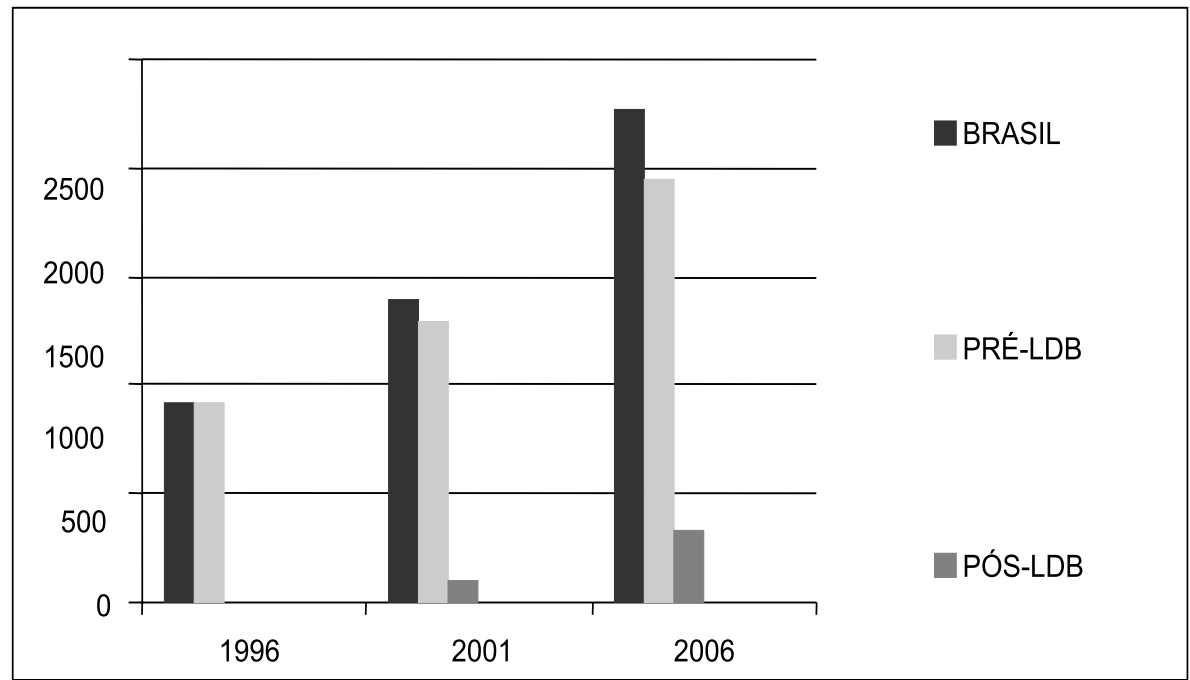

Gráfico 6 - Evolução das IES pré-LDBEN/96 e pós-LDBEN/96 - Brasil, 1996 a 2006. Fonte: INEP (1999, 2002, 2007).

Em conjunto, as novas IES tiveram um crescimento de $227 \%$ somente no período 2001-2006, percentual bem acima dos 50,5\% das IES tradicionais. Vale destacar que a Tabela 8 indica que somente os Centros de Educação Tecnológica e as Faculdades de Tecnologia tiveram, em conjunto, um aumento de 581\% nesse mesmo período, contra $80,3 \%$ dos Centros Universitários. E, afinal, qual o perfil dessas novas instituições?

\section{Os Centros Universitários}

Na LDBEN/96 (BRASIL, 1996), embora o capitulo específico sobre educação superior seja o que contém o maior número de artigos, há omissões em relação às novas figuras institucionais como a do centro universitário. Ao tratar da educação superior, a Lei prevê apenas, em seu artigo 45, que esta "será ministrada em instituições de ensino superior públicas ou privadas, com vários graus de abrangência e especialização" (BRASIL, 1996), sem maiores especificações.

0 primeiro semestre de 1997 foi tomado por intensa produção de dispositivos legais e de textos para a construção de um quadro de referências sobre os centros universitários. As discussões desenvolvidas no Seminário "A Construção do Projeto dos Centros Universitários: orientações do MEC e realidade das escolas", realizado em agosto desse mesmo ano, retratam com clareza as primeiras indicações legais sobre o assunto e as questões mais polêmicas em relação à criação dessa nova figura institucional. 
0s Centros Universitários foram definidos pelo Artigo 12 do Decreto 2.306, de 19 de agosto de 1997 (BRASIL, 1997b), como IES pluricurriculares, abrangendo uma ou mais áreas de conhecimento, que se caracterizam pela qualidade do ensino oferecido e usufruem como instituições universitárias, a autonomia para criar, organizar e extinguir, em sua sede, cursos e programas, bem como remanejar ou ampliar vagas nos cursos existentes.

Ao descrever os aspectos legais dos centros universitários, a professora Eurides Brito da Silva (1997, p. 10) apresenta as fontes de sua definição inicial: "0 Decreto n. 2.207/97 e a Portaria n. 639/97 estabeleceram, oficialmente, a tipologia das instituições de ensino superior, regulamentando o disposto no art. 45 da Lei n. 9.394/96". Consoante o Decreto n. 2.207, de 15 de abril de 1997 (BRASIL, 1997a), em seu artigo $6^{\circ}$, esses centros são definidos como

$$
\begin{aligned}
& \text { [...] instituições de ensino superior pluricurriculares, } \\
& \text { abrangendo uma ou mais áreas do conhecimento, que } \\
& \text { se caracterizam pela excelência do ensino oferecido, } \\
& \text { comprovada pela qualificação do seu corpo docente e } \\
& \text { pelas condições de trabalho acadêmico oferecidas à co- } \\
& \text { munidade escolar, nos termos das normas estabelecidas } \\
& \text { pelo Ministro de Estado da Educação e do Desporto para } \\
& \text { seu credenciamento. }
\end{aligned}
$$

Nesse quadro, chama a atenção o fato de que as características consideradas facultativas - pós-graduação stricto sensu, percentual mínimo de qualificação e dedicação do corpo docente, assim como produção sistematizada de pesquisas -, são justamente aquelas que elevam o custo de manutenção da IES (preocupação maior dos provedores das instituições), mas, por outro lado, têm estreita relação com a "excelência do ensino" que, segundo o próprio Decreto, deve ser comprovada pela qualificação do seu corpo docente e pelas condições de trabalho acadêmico oferecidas à comunidade escolar.

Dois decretos, no decorrer do Governo Lula, merecem destaque, no que se refere à configuração dos centros universitários no sistema da educação superior: o Decreto $n^{\circ}$. 4.914, de 11 de dezembro de 2003, expedido no início de seu primeiro mandato (BRASIL, 2003) e o Decreto $n^{\circ}$. 5.786, de 24 de maio de 2006, no segundo mandato (BRASIL, 2006a). Procuramos identificar as diferenças entre os dois decretos, em termos da concepção de centro universitário, por meio de um quadro comparativo das duas medidas legais. Elas estão destacadas, em negrito, no Quadro 2. 


\begin{tabular}{|c|c|}
\hline Decreto $n \cdot 4.914 / 2003$ & Decreto $n \cdot 5.786 / 2006$ \\
\hline $\begin{array}{l}\text { Art. } 1^{\circ} \text { Fica vedada a constituição de novos } \\
\text { centros universitários, exceto aqueles em fase } \\
\text { de tramitação no Ministério de Educação } \\
\text { para credenciamento [...] ficando restritos os } \\
\text { seus cursos e vagas ao limite constante do } \\
\text { seu Plano de Desenvolvimento Institucional - } \\
\text { PDI [...] }\end{array}$ & $\begin{array}{l}\text { Art. } 2^{\circ} \text { - Os centros universitários, observado } \\
\text { o disposto no Decreto no } 5773 \text { de } 9 \text { de maio } \\
\text { de } 2006 \text {, poderão criar, organizar e extin- } \\
\text { guir, em sua sede, cursos e programas de } \\
\text { educação superior, assim como remanejar } \\
\text { ou ampliar vagas nos cursos nos termos } \\
\text { deste decreto. }\end{array}$ \\
\hline \multirow{5}{*}{$\begin{array}{l}\text { Art. } 2^{\circ} \text { Os centros universitários já credencia- } \\
\text { dos e os de que trata o artigo } 1^{\circ} \text {, se credencia- } \\
\text { dos, deverão comprovar, até } 31 \text { de dezembro } \\
\text { de } 2007 \text {, que satisfazem o princípio da indis- } \\
\text { sociabilidade entre ensino, pesquisa e ex- } \\
\text { tensão [...] sendo que os trinta e três por cen- } \\
\text { to do corpo docente em regime de tempo } \\
\text { integral [...] }\end{array}$} & $\begin{array}{l}\text { Art. } 1^{\circ} \text { - Os centros universitários são institui- } \\
\text { ções de ensino superior pluricurriculares, que } \\
\text { se caracterizam pela excelência do ensino } \\
\text { oferecido, pela qualificação do seu corpo } \\
\text { docente e pelas condições de trabalho aca- } \\
\text { dêmico oferecidas à comunidade escolar. [...] }\end{array}$ \\
\hline & $\begin{array}{l}\text { Parágrafo único. [...] que atendam aos se- } \\
\text { guintes requisitos: }\end{array}$ \\
\hline & $\begin{array}{l}\text { I um quinto do corpo docente em tempo } \\
\text { integral }\end{array}$ \\
\hline & $\begin{array}{l}\text { Il um terço do corpo docente, pelo menos, } \\
\text { com titulação acadêmica de mestrado ou } \\
\text { doutorado. }\end{array}$ \\
\hline & $\begin{array}{l}\text { Art. } 2^{\circ} \S 4^{\circ} \text { Os centros universitários poderão } \\
\text { registrar diplomas dos cursos por eles ofere- } \\
\text { cidos. }\end{array}$ \\
\hline
\end{tabular}

Quadro 2 - Concepção e grau de autonomia dos centros universitários nos decretos $n^{\circ}$. 4.914/2003 e $n^{\circ}$. 5.786/2006.

Fonte: Fávero e Segenreich (2008, p. 175, grifo nosso).

A primeira coluna do Quadro 2 oferece uma visão clara da tentativa do governo federal, que se iniciava em 2003, no sentido de aproximar a concepção de centro universitário á concepção de universidade, ao introduzir em seu Artigo $2^{\circ}$ a exigência de comprovação do princípio da indissociabilidade entre ensino, pesquisa e extensão para seu credenciamento, conjugada ao estabelecimento de um percentual mínimo de professores em tempo integral. Entretanto, no decreto de maio de 2006, constante da segunda coluna, não somente se volta à definição de centro universitário de 1997, em que se enfatiza a excelência do ensino sem menção à indissociabilidade entre ensino e pesquisa, como também é reduzido de 33\% para 20\% o percentual mínimo de professores em tempo integral a ser exigido nas avaliações. Quanto ao grau de autonomia, o segundo decreto atende aos principais interesses das mantenedoras dessas IES, na medida em quê mantêm seu direito de criar, organizar e extinguir cursos e programas de educação superior, assim como remanejar ou ampliar vagas nos cursos. 
Ao se caracterizar a concepção e o grau de autonomia de centro universitário, preconizados na legislação vigente, foi possivel perceber que prevaleceu a visão de uma instituição que tem, praticamente, todas as prerrogativas de autonomia da universidade sem a obrigação de desenvolver institucionalmente a pós-graduação stricto sensu e a pesquisa.

Continuando essa análise, pretendemos identificar qual o espaço que vem sendo ocupado por essa nova forma de instituição no âmbito do sistema brasileiro de educação superior.

Tabela 10 - Evolução do número de centros universitários por categoria administrativa, - Brasil, 1997 a 2006.

\begin{tabular}{l|c|c|c}
\hline Ano & Brasil & Pública & Privada \\
\hline 1997 & 13 & - & 13 \\
\hline 2001 & 66 & 2 & 64 \\
\hline 2006 & 119 & 4 & 115 \\
\hline
\end{tabular}

Fonte: INEP (1999, 2002, 2007).

Na medida em que se delimita o período de tempo de análise, a partir da criação dos primeiros centros universitários, em 1997, é possivel perceber a crescente presença desse tipo de IES que apresentou um percentual de crescimento de $815,4 \%$ no periodo 1997-2006, a maioria na rede privada. Os quatro centros universitários públicos existentes em todo o Brasil surgiram a partir do ano de 2000, todos na rede municipal, localizando-se nos Estados de São Paulo (dois centros), Minas Gerais (um centro) e Santa Catarina (um centro), segundo os dados do INEP (2002).

Os índices de crescimento dos centros universitários diminuíram no período 2001 2006, em relação ao período 1997-2001 por causa, talvez, da indefinição legal e posterior promulgação de uma legislação mais rigorosa, o Decreto nº 4.914 (BRASIL, 2003). Os atuais acontecimentos permitem prever uma tendência de aumento de espaço desse tipo de instituição no sistema, nos próximos anos, principalmente se forem levadas em consideração as condições facilitadoras que foram introduzidas mediante o Decreto $n^{\circ}$. 5.786 (BRASIL, 2006), aliadas à proximidade dos prazos estabelecidos pelo Plano Nacional de Educação para que as atuais universidades cumprissem uma série de requisitos a fim de manterem essa forma jurídica. Um estudo de Segenreich (2001, p. 208) sobre a relação entre ensino de graduação e pesquisa, já assinalava:

No que se refere às atuais políticas públicas relacionadas à questão, o discurso passa pela negação da indissociabilidade ensino-pesquisa, vista como pesquisa científica, em nível individual (do professor) e pela restrição deste preceito constitucional às universidades que realmente desenvolvam pes-

Ensaio: aval. pol. públ. Educ., Rio de Janeiro, v. 17, n. 62, p. 55-86, jan./mar. 2009 
quisa. Isto significa que as demais universidades ou se tornarão Universidades Classe B ou serão descredenciadas, engrossando o número de centros universitários já existentes.

\section{Os Centros de Educação Tecnológica e Faculdades de Tecnologia}

As Escolas Técnicas Federais foram criadas em 1942, oferecendo formação técnica de nivel médio e servindo durante muito tempo como laboratório e modelo de propostas educacionais técnicas. 0 Ministério de Educação e Cultura (MEC), através da Diretoria de Assuntos Universitários (DAU), em 1962, sugeriu a criação de cursos de engenharia de operação, de curta duração, aprovados pelo Parecer n. 60/1963 do Conselho Federal de Educação (CFE) com o objetivo de atender as necessidades da indústria, principalmente a automobilística, que passou a exigir profissionais mais qualificados. Em 1965, foi autorizado o funcionamento desses cursos na Escola Técnica Federal do Rio de Janeiro, em convênio com a Universidade Federal do Rio de Janeiro, e em São Paulo, oferecidos pela Faculdade de Engenharia Industrial (FEI). Tais cursos ficaram caracterizados como cursos técnicos de nivel superior, que ofertavam "habilitação profissional intermediária entre o técnico de nivel médio e o engenheiro". Foram alvos de discriminação por parte dos engenheiros e duraram pouco mais de dez anos (CONSELHO NACIONAL DE EDUCAÇÃO, 2002).

Em 1977, um grupo de resoluções organizou o curso de engenharia industrial, marcando para 01/01/1979, a data limite para que fossem sustados os vestibulares para o curso de engenharia de operação. Como consequência, em 1978, a partir da Lei n. 6.545 (BRASIL, 1978), as Escolas Técnicas Federais de Minas Gerais, Rio de Janeiro e São Paulo foram transformadas em Centros Federais de Educação Tecnológica (CEFETs).

Os CEFETs tiveram ampliadas sua autonomia administrativa e pedagógica, tornaram-se centros de referência de educação técnica e tecnológica e possuiam, entre seus objetivos o de ministrar ensino em grau superior de graduação e pósgraduação e realizar pesquisas na área técnica industrial (BOCCHETTI, 1997).

Campello (2006, p. 35-36), ao analisar a Lei nº 6.545 (BRASIL, 1978), ressalta que os CEFETs foram criados como instituições predominantemente de ensino superior, tanto no que se refere a questões administrativas, quanto em relação a seus objetivos educacionais. De acordo essa autora, a transformação das Escolas Técnicas Federais em CEFETs demandou a ampliação dessas instituições que continuaram a oferecer o ensino médio técnico, mas passaram também a atuar no ensino superior. Essa transformação não acarretou mudança ou solução de continuidade quanto à oferta do ensino técnico de $2^{\circ}$ Grau, pois na prática os CEFETs passaram a conviver com duas escolas:

Uma escola técnica com seus cursos integrados ao ensino médio e que, tomando-se como exemplo o CEFET/JR [empresa junior do CEFET do Rio Grande do Norte], forma técni-

Ensaio: aval. pol. públ. Educ., Rio de Janeiro, v. 17, n. 62, p. 55-86, jan./mar. 2009 
cos em Eletrônica, Eletrotécnica, Mecânica, Meteorologia e Construção Civil, e uma faculdade de Engenharia que oferece cursos de Engenharia Mecânica e Elétrica e cursos de pósgraduação, também na área das engenharias. Em outras palavras, no que diz respeito à oferta educativa, a característica da "cefetização" dos anos 1970 é de acréscimo nas atribuições das escolas técnicas, que passam também a oferecer cursos de nivel superior (CAMPELLO, 2006, p. 38).

Em 1994, a Lei nº 8.948 (BRASIL, 1994) instituiu o Sistema Nacional de Educação Tecnológica, "integrado pelas instituições de educação tecnológica, vinculadas ou subordinadas ao Ministério da Educação e do Desporto e sistemas congêneres dos Estados, dos Municipios e do Distrito Federal" (art. 10). No parágrafo $1^{\circ}$, a Lei estabelece que "a participação da rede particular no Sistema Nacional de Educação Tecnológica poderá ocorrer, ouvidos os respectivos órgãos superiores deliberativos".

Um ano após a aprovação da LDBN (BRASIL, 1996), o Decreto Federal n. 2.406 (BRASIL, 1997c) regulamentou a Lei n. 8.948 (BRASIL, 1994), alterando a natureza dos Centros de Educação Tecnológica (CET), transformando-os em "instituições especializadas de educação profissional" (art. $1^{\circ}$.) e definindo que:

Os Centros de Educação Tecnológica, públicos ou privados, têm por finalidade formar e qualificar profissionais, nos vários níveis e modalidades de ensino, para os diversos setores da economia e realizar pesquisa e desenvolvimento tecnológico de novos processos, produtos e serviços, em estreita articulação com os setores produtivos e a sociedade, oferecendo mecanismos para a educação continuada.

Campello (2006) observa que a criação dos CETs aproveita a infraestrutura da rede de escolas técnicas federais e a legislação também existente "desde os tempos do governo Itamar Franco"3. Afinal, a Lei no. 8.948 (BRASIL, 1994), já dispunha "sobre a instituição do Sistema Nacional de Educação Tecnológica e a transformação das escolas técnicas federais em CEFETs, e que tinha permanecido sem aplicação". Em nota, a autora explica que o processo de "cefetização", concretizado a partir de 1999, das escolas técnicas federais é acompanhado pela criação dos CETs privados, com apoio de verbas do Programa de Expansão da Educação Profissional (PROEP), "o chamado segmento comunitário do PROEP" e exemplifica mencionando o fato de terem sido credenciados vinte e um CETs privados em 2001 (CAMPELLO, 2006, p. 43).

Em outubro de 2004, o Decreto n. 5.224 (BRASIL, 2004a) dispôs sobre a organização dos CEFETs, estabelecendo sua natureza, finalidades, característica, objetivos e estrutura organizacional, bem como sua autonomia para oferta de cursos e processos de credenciamento e recredenciamento.

${ }_{3}$ De 29/12/1992 a 1/01/1995. 
Neste Decreto (BRASIL, 2004a), os "CEFETs são instituições especializadas na oferta de educação tecnológica, nos diferentes níveis e modalidades de ensino, com atuação prioritária na área tecnológica" (art. $1^{\circ}$. $\$ 1^{\circ}$ ). Sua finalidade é formar e qualificar profissionais na área tecnológica, para diferentes setores da economia, além de "realizar pesquisa aplicada e promover o desenvolvimento tecnológico de novos processos, produtos e serviços", articulando-se com os setores produtivos e a sociedade (art. $2^{\circ}$.).

Assim colocado, o Decreto (BRASIL, 2004a) alargou as funções dos CEFETs, tendo em vista a possibilidade de realização de pesquisa aplicada, inserida no processo de desenvolvimento educacional, favorecendo, permanentemente, a transformação do conhecimento em bens e serviços, a fim de beneficiar a sociedade, bem como a comunidade onde está inserido.

Vale ressaltar duas questões importantes na análise dos dados estatísticos sobre esse tipo de instituição: em primeiro lugar, as sinopses do Censo da Educação Superior do INEP $(1999,2002,2007)$ começam a discriminar essa forma de organização acadêmica no capitulo relativo às IES apenas no ano de 1999. No entanto, não quer dizer que este tipo de instituição não existisse, ao contrário. Até 1997 as Escolas Técnicas Federais foram responsáveis pela formação de muitos alunos em cursos tecnológicos (utilizando a terminologia atual).

Em todo o pais, entre 1999 e 2006, os Centros de Educação Tecnológica (CETs) e as Faculdades Tecnológicas (FATs) tiveram expansão considerável, passando de 16, em 1999 para 208, em 2006, conforme demonstram a Tabela 11 e o Gráfico 10, que apresentam os dados referentes a essas instituições por categoria administrativa.

Tabela 11 - Distribuição dos CET/FAT e percentual de crescimento por categoria administrativa (pública e privada) - Brasil, 1999 a 2006.

\begin{tabular}{l|r|r|r|r|r}
\hline \multirow{2}{*}{ Ano } & \multirow{2}{*}{ Brasil } & \multicolumn{2}{|c|}{ Pública } & \multicolumn{2}{|c}{ Privada } \\
\cline { 3 - 6 } & & Total & $\%$ & Total & $\%$ \\
\hline 1999 & 16 & 16 & 100,0 & - & - \\
\hline 2001 & 34 & 26 & 76,5 & 8 & 23.5 \\
\hline 2006 & 208 & 66 & 31,7 & 142 & 68,3 \\
\hline $2001 / 2006 \Delta \%$ & 511,8 & 153,8 & - & 1675,0 & - \\
\hline
\end{tabular}

Fonte: INEP (1999, 2002, 2007). 
Pode-se verificar na Tabela 11 que o primeiro setor a investir em instituições tecnológicas foi o setor público, que em 1999 possuía 16 unidades, enquanto que as primeiras instituições privadas surgem apenas em 2001, com 8 unidades em todo 0 país. Houve expansão nas duas categorias administrativas (pública e privada), mas os percentuais de crescimento não foram os mesmos. Entre 2001 e 2006, enquanto a rede pública crescia de 26 para 66 unidades $(153,8 \%)$, a rede privada avançava de 8 para $142(1.675 \%)$. Uma consequência evidente deste desnivel nos percentuais de crescimento foi a inversão de predominância das esferas públicas e privadas. A esfera privada passa de uma participação de 23,5\% do total de IES, em 2001, para 68,35 em 2006. Esta inversão de perfil pode ser claramente visualizada no Gráfico 7.

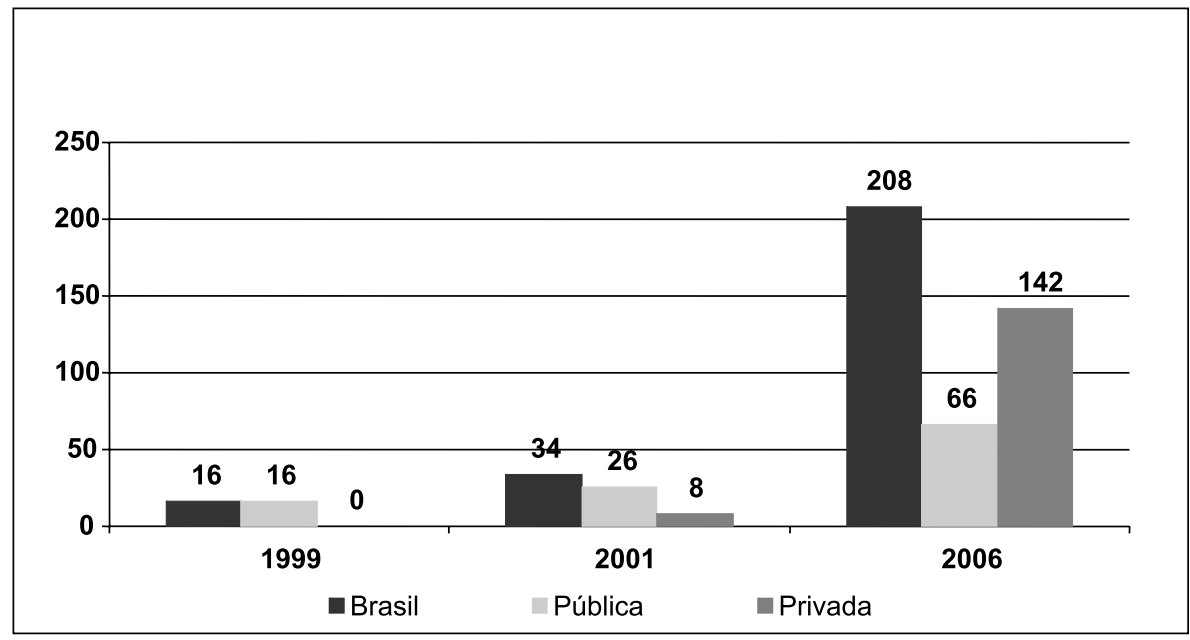

Gráfico 7 - Número de CET/FAT, por Categoria Administrativa - Brasil - 1999/2006. Fonte: INEP $(1999,2002,2007)$.

\section{O espaço dos novos tipos de curso e novas modalidades de ensino no sistema de educação superior em expansão}

Entre os novos tipos de curso destaca-se a criação dos cursos sequenciais e o novo perfil dos cursos superiores de tecnologia. Quanto à modalidade de ensino, estamos falando, obviamente, da educação a distância.

\section{Os cursos superiores de tecnologia}

$\mathrm{Na}$ realidade, os cursos superiores de tecnologia não são uma criação da LDBEN (BRASIL, 1996), pois já existiram e foram extintos - como, por exemplo, os cursos de engenharia de operação - , ou ainda subsistem sob a rubrica de curso de formação de tecnólogos. 0 que é novo, a partir da Lei n. 9.394 (BRA- 
SIL, 1996), é sua inclusão entre os cursos de graduação com todas as prerrogativas de acesso aos níveis mais elevados da formação em nível superior. Esta política se evidencia no fato de o INEP não diferenciar, em suas estatísticas mais gerais, os bacharelados, licenciaturas ou cursos de tecnologia. Entretanto, ao se analisar a oferta de cursos pelos CEATs e FATs assim como dos cursos de graduação a distância, que vêm crescendo significativamente no Brasil, iremos perceber a presença desse tipo de curso, tendo em vista que as estatísticas do MEC apresentam os dados da educação a distância por instituição e curso. No que se refere à oferta de cursos pelos CEATs e FATs, a Tabela 12 dá uma visão de como esses cursos se comportam.

Tabela 12 - Distribuição dos cursos oferecidos pelos CET/FAT e percentual de crescimento por categoria administrativa (pública e privada) - Brasil 1999 a 2006.

\begin{tabular}{l|r|r|r|r|r}
\hline \multirow{2}{*}{ Ano } & \multirow{2}{*}{ Brasil } & \multicolumn{2}{|c|}{ Pública } & \multicolumn{2}{|c}{ Privada } \\
\cline { 3 - 6 } & & Total & $\%$ & Total & $\%$ \\
\hline 1999 & 74 & 74 & 100 & - & -- \\
\hline 2001 & 183 & 153 & 83,6 & 30 & 16,4 \\
\hline 2006 & 959 & 360 & 37,5 & 599 & 62,5 \\
\hline $2001 / 2006 \bullet \%$ & 424,0 & 135,3 & - & $1.896,7$ & - \\
\hline
\end{tabular}

Fonte: INEP (1999, 2002, 2007).

Os dados da Tabela 12 ratificam as mesmas tendências de rápida privatização do setor, verificadas quando da análise do perfil e evolução quantitativa das IES voltadas para a educação tecnológica.

\section{Os cursos sequenciais}

Em relação aos cursos sequenciais, eles realmente foram incluídos pela primeira vez no Artigo 39 da LDBEN (BRASIL, 1996), junto com os tradicionais cursos de graduação, pós-graduação e extensão. Entretanto, eles ficaram aguardando uma posterior definição. Sua regulamentação foi construida por sucessivos pareceres do Conselho Federal de Educação, de 1997 a 1999, ficando estabelecidos, finalmente, dois tipos de cursos sequenciais: os de complementação de estudos de destinação coletiva e os de formação específica.

0 curso sequencial de complementação de estudos de destinação coletiva se aproxima mais da proposta do prof. Darcy Ribeiro, para a Lei de Diretrizes e Bases. Nessa concepção, estes cursos eram de destinação individual e deveriam constituirse como uma alternativa à rigidez dos cursos de graduação, permitindo que estudantes realizassem estudos pós-médios de seu interesse profissional imediato, sem buscar graus acadêmicos. Tais cursos não foram incluídos no presente estudo. 
Expansão, privatização e diferenciação da educação superior

A ideia de curso sequencial de formação especifica surgiu no processo de regulamentação dos cursos sequenciais e veio, na realidade, atender aos interesses das IES no sentido de oferecer cursos de curta duração, mais voltados para o mercado de trabalho e que fornecessem diplomas. No momento, esses cursos constam das estatísticas oficiais, apresentando-se nas modalidades presencial e a distância. A Tabela 13 apresenta a situação desses cursos no período 2001-2006.

Tabela 13 - Distribuição do número de cursos sequenciais presenciais de formação especifica por categoria administrativa (pública e privada) - Brasil, 2001 a 2006.

\begin{tabular}{l|r|r|r|r|r}
\hline \multirow{2}{*}{ Ano } & \multirow{2}{*}{ Total } & \multicolumn{2}{|c|}{ Pública } & \multicolumn{2}{c}{ Privada } \\
\cline { 3 - 6 } & & Total & $\%$ & Total & $\%$ \\
\hline 1999 & 74 & 74 & 100 & - & -- \\
\hline 2001 & 328 & 91 & 27,7 & 237 & 72,3 \\
\hline 2006 & 652 & 184 & 28,2 & 468 & 71,8 \\
\hline $2001 / 2006 " \%$ & 98,8 & 102,2 & - & 97,5 & - \\
\hline
\end{tabular}

Fonte: INEP (1999, 2002, 2007).

Em relação à oferta de cursos sequenciais presenciais de formação especifica, pode-se perceber, na Tabela 13, um percentual significativo de crescimento dos cursos em geral (98,8\%), sem grandes diferenças entre as esferas pública e privada. Entretanto, a entrada maciça da rede privada, logo que foi aberta esta possibilidade, ainda Ihe garante um percentual elevado de participação no total de cursos oferecidos (cerca de 70\% tanto em 2001 como em 2006). A tendência de crescimento desse tipo de curso merece ser mais estudada.

Quanto aos cursos sequenciais de formação específica a distância, não se evidencia um interesse muito significativo por este tipo de curso nem na esfera pública, nem na privada; os dados do Censo do INEP registram três cursos em 2001 e 17 cursos em 2006. Consultando as sinopses estatísticas, pôde-se constatar que os 17 cursos ofertados em 2006 estão sob a responsabilidade de, somente, seis instituições de ensino superior: Universidade de Caxias do Sul, Pontifícia Universidade Católica de Campinas, Universidade da Amazônia, Universidade Anhembi Morumbi, Universidade do Tocantins e Faculdade de Administração de Brasilia.

Uma hipótese para este tipo de comportamento sugere que as IES estão preferindo investir nos cursos superiores de tecnologia, que são considerados como curso de graduação, com todas as prerrogativas que estes cursos conferem. Entretanto, se os cursos sequenciais a distância não parecem despertar o interesse das IES, o mesmo não se pode dizer dos cursos de graduação a distância - sabendo-se, inclusive, que neles estão incluídos, também, os cursos superiores de tecnologia. 


\section{Os cursos de graduação a distância}

No início do governo Lula, vários trabalhos procuram analisar as políticas públicas para a educação superior, vigentes no pais. Um tema que vinha atraindo atenção e críticas nas reuniões da Associação Nacional de Pós-Graduação e Pesquisa em Educação (ANPEd), relacionava-se à proposta de uma crescente utilização da Educação a Distância (EAD) neste nível de ensino, principalmente na formação de professores para o ensino básico (SILVA JÚNIOR, 2002). A tônica das críticas centravase na percepção de que, além de não poder substituir a interação professor-aluno, inerente à educação presencial, a EAD seria uma das estratégias de organismos internacionais como o Banco Mundial e a Organização Mundial do Comércio para a mercantilização e privatização do ensino superior.

Constatou-se, com base em documentos do Ministério da Educação (MEC) e em outros trabalhos especializados (VIANNEY; TORRES; SILVA, 2003; MAIA, 2002), que:

1. em relação à presença de cursos de graduação a distância, era preponderante a presença das licenciaturas para as primeiras séries iniciais com um número significativo de alunos (77\% de um total de 84723 alunos).

2. era também preponderante a presença de universidade públicas entre as instituições de ensino superior (IES) credenciadas pelo MEC, e de consórcios ou redes em torno de um projeto específico de formação de professores, como no caso do Projeto Veredas em Minas Gerais, ou formação em nível de graduação como estratégia de expansão do ensino superior, como no caso do Centro de Educação a Distância do Estado do Rio de Janeiro (CEDERJ).

Após três anos, nova oportunidade de discussão dos caminhos das políticas públicas para a EAD se apresenta tendo em vista que foi finalmente aprovada, em dezembro de 2005, a nova regulamentação da Educação a Distância (BRASIL, 2005a).

Para melhor analisar a questão da EAD faz-se necessário ter uma ideia, a mais clara possivel de sua dimensão neste início de século. Este já é o primeiro desafio a ser enfrentado, porque é grande a carência de dados quantitativos e qualitativos sobre a presença da EAD no sistema de educação superior, tendo em vista que os cursos de graduação a distância somente constam dos Censos do INEP a partir do ano 2000.

Na Tabela 14 pode-se ter uma visão do ritmo de concessão de credenciamento a diferentes tipos de IES para oferta de cursos de graduação a distância, tomando como base os registros dos Censos do INEP. Neles não estão incluídos nem os CEATs nem as FATs. 
Expansão, privatização e diferenciação da educação superior

Tabela 14 - Evolução do número de IES oferecendo cursos de graduação a distância segundo organização acadêmica e categoria administrativa - Brasil, 2001 a 2006.

\begin{tabular}{l|c|c|c|c|c|c}
\hline \multicolumn{2}{|c|}{} & Pública & \multicolumn{4}{|c}{ Privada } \\
\hline Ano & $\begin{array}{c}\text { Total } \\
\text { Brasil }\end{array}$ & $\begin{array}{c}\text { Total } \\
\text { Universidades }\end{array}$ & Total & Universidade & $\begin{array}{c}\text { Centro } \\
\text { Universitário }\end{array}$ & $\begin{array}{c}\text { Faculdade/ } \\
\text { Faculd. int./ } \\
\text { Institutos }\end{array}$ \\
\hline 2001 & 10 & 09 & 01 & 01 & - & - \\
\hline 2006 & 75 & 27 & 48 & 22 & 10 & 16 \\
\hline$\Delta \% 2001 / 2006$ & 650,0 & 200,0 & $4.700,0$ & 2.100 & - & - \\
\hline
\end{tabular}

Fonte: INEP (1999, 2002, 2007).

Pode-se verificar em 2001 a existência de 10 instituições credenciadas para ministrar cursos de graduação. Somente em 2004 foram concedidos 27 novos credenciamentos, e este ritmo acelerado se vem mantendo. Analisando as taxas de crescimento por esfera administrativa no período 2001-2006, chama a atenção a disparidade entre o crescimento da rede pública $(200,0 \%)$ em relação à rede privada (4.700 \%). Não é surpresa a inversão da balança em relação à situação existente em 2001, que registrava a predominância das IES - todas universidades - do setor público (90\%). Em 2006 os pratos da balança se invertem, e as 48 IES do setor privado passam a representar $64,0 \%$ das instituições que estão oferecendo cursos de graduação a distância. Permanece, ainda, uma predominância das universidades (74\%) - públicas e privadas - na oferta de cursos, mas os centros universitários e faculdades/associação de faculdades já representam mais de 50\% das IES do setor privado na modalidade a distância.

0 passo seguinte foi buscar, nas sinopses do INEP, dados sobre a oferta de cursos, matrículas e vagas ociosas (ponto já detectado como crítico nessa análise). Na Tabela 15 é possivel se ter uma ideia do crescimento vertiginoso dessa modalidade de ensino, apesar de algumas distorções observadas no modo de se registrarem os dados ${ }^{4}$.

Tabela 15 - Evolução do número de cursos de graduação a distância, matrículas e vagas ociosas no período- Brasil, 2000 a 2006.

\begin{tabular}{l|c|c|c|c}
\hline Ano & Cursos $^{*}$ & Cursos* $^{* *}$ & Matrícula & Vagas ociosas \\
\hline 2001 & 16 & 10 & 5.359 & 238 \\
\hline 2006 & 349 & 231 & 207.206 & 601.304 \\
\hline$\Delta \% 2001 / 2006$ & 2081,3 & $2.200,0$ & $3.766,5$ & $25.2548,8$ \\
\hline
\end{tabular}

Transcrição direta da fonte MEC

** Levantamento reinterpretado da fonte MEC

Fonte: INEP (1999, 2002, 2007).

4 No registro do número de cursos, o INEP contou cada pólo de apoio como um curso apesar de tratar-se do mesmo curso reproduzido para diferentes pólos.

Ensaio: aval. pol. públ. Educ., Rio de Janeiro, v. 17, n. 62, p. 55-86, jan./mar. 2009 
Os dados da Tabela 15 permitem verificar o ritmo crescente de expansão dos cursos oferecidos nessa modalidade, chegando a um aumento percentual de 2.200 $\%$, no periodo de 2001 a 2006. Um dos pontos que chamam mais atenção nessa mesma tabela, em relação aos cursos de graduação, é um aumento vertiginoso de oferta de vagas a partir de 2003 sem ser acompanhado por um aumento suficiente de ingressantes para preenchê-las, ocasionando elevado número de vagas ociosas. A questão das vagas ociosas na rede privada vai gerar um programa do governo que terá por objetivo utilizar essas vagas para atingir as metas estabelecidas pelo Plano Nacional de Educação, incluindo a EAD como uma de suas possibilidades.

Realmente, na mesma época da aprovação, em dezembro de 2005, da regulamentação da Educação a Distância (BRASIL, 2005a), alguns programas governamentais passaram a se valer da EAD como política pública de expansão da educação superior, dentre os quais se destacam o Programa Universidade para Todos (ProUni) e o Projeto Universidade Aberta do Brasil (UAB).

O ProUni foi criado pela Medida Provisória n. 213, de 10 de setembro de 2004, e finalmente transformado em lei - Lei n. 11.096, de 13 de janeiro de 2005 - no ano seguinte (BRASIL, 2005b). 0 Programa consiste no oferecimento de bolsas de estudos, em IES privadas, a estudantes de baixa renda sem diploma de nivel superior, traduzindo-se em benefício concedido ao estudante, na forma de desconto parcial ou integral sobre os valores cobrados pelas IES participantes do Programa. De acordo com o discurso governamental, trata-se de uma política estratégica que visa a solucionar a insuficiência de oferta na educação superior brasileira e atender às prioridades estabelecidas pelo Plano Nacional de Educação, já mencionadas nesse texto.

0 discurso de democratização do acesso ao ensino superior do governo, em relação ao ProUni, recebeu muitas críticas por representar o aprofundamento da privatização do ensino superior, tanto na época de sua criação como no decorrer do seu processo de implantação.

Merece destaque a crítica levantada por um grupo dissidente do movimento estudantil, Juventude Libertária da Resistência Popular, apontando para o fato de que, "na troca do investimento público pela compra de vagas privadas, o governo está privilegiando, mais uma vez, as regiões mais ricas do país, pois nelas estão concentradas as universidades particulares" (JUVENTUDE LIBERTÁRIA DA RESISTÊNCIA POPULAR, [2008?], p.1). Esta crítica alertou para um aspecto importante da implantação desse Programa. Realmente, em alguns estados do Norte e do Nordeste, há poucas instituições particulares e, com isso, poucas vagas que podem ser aproveitadas pelo ProUni, o que permitiu se levantar a hipótese de que o governo talvez pudesse se valer dos cursos a distância para preencher esses claros. Apesar de não existirem dados oficiais sobre a oferta de bolsas do ProUni para cursos de EAD, tem sido possivel verificar a 
Expansão, privatização e diferenciação da educação superior

existência delas no momento em que o MEC disponibiliza instituições e cursos integrantes do ProUni para a inscrição dos candidatos. Em 2008.1 este número chegou a 2.866 bolsas somente para as Regiões Norte e Nordeste.

Considera-se que existe uma tendência de EAD ocupar cada vez mais espaço no ProUni e, consequentemente na política de expansão do sistema de educação superior. Para melhor avaliar essa tendência faz-se necessário que o MEC disponibilize dados mais diversificados sobre o Programa.

Finalmente, não se pode deixar de destacar o Projeto Universidade Aberta do Brasil (UAB), instituído também em 2005 em parceria com o Fórum das Estatais, para articular e integrar um sistema nacional de educação superior a distância. No decorrer de 2006, o Projeto desenvolveu o curso-piloto de Administração a Distância, com 10.000 vagas, por meio de uma parceria entre a Secretaria de Educação a Distância do MEC, Banco do Brasil e um conjunto de 18 universidades federais e sete estaduais. Esta iniciativa (BRASIL, 2006b) logo deverá ser, obrigatoriamente, objeto de estudo específico, por sua magnitude e impacto no sistema de educação superior como um todo. Segundo notícias veiculadas pelo MEC, diversas universidades federais estão oferecendo elevado número de vagas para os cursos da $U A B$, o que, certamente terá impacto no perfil de expansão do ensino superior nos próximos anos.

Pode-se verificar que os novos cursos, especialmente os de graduação a distância, os cursos sequenciais presenciais e, principalmente, os cursos superiores de tecnologia - presenciais e a distância - estão expandido gradativamente sua área de atuação apesar de a grande maioria de cursos ser ainda de graduação presencial. Como vão se comportar esses cursos nos próximos anos deve ser motivo de profundo debate.

\section{Considerações finais: algumas tendências como hipóteses de trabalho}

0 que se pôde observar nos dados apresentados é que a privatização, em termos de crescimento das IES privadas/particulares, marcou o período 1996 - 2001. Isto se fez sentir mais fortemente no aumento exagerado da oferta de vagas para a demanda existente, o que gerou uma "bola de neve" de estoque de vagas ociosas no sistema de educação superior. Mais uma vez o governo acabou por socorrer, de certa forma, essas instituições, por intermédio do ProUni.

No período de 2001 a 2006, o ritmo de crescimento dessas instituições diminuiu, porém é ainda significativamente ascendente, como mostram as estatísticas; destacando-se, no período, a expansão dos centros universitários e de educação tecnológica. Entretanto, a expansão das instituições particulares, principalmente

Ensaio: aval. pol. públ. Educ., Rio de Janeiro, v. 17, n. 62, p. 55-86, jan./mar. 2009 
universidades e centros universitários, vem trilhando caminhos alternativos, em termos de tipo de curso oferecido - cursos superiores de tecnologia - e/ou modalidade de ensino - educação a distância. Nesse ponto privatização e diferenciação se complementam, na perspectiva mercadológica que domina a expansão do ensino superior no Brasil. Uma análise das IES que oferecem cursos de graduação a distância, disponivel nos registros do INEP pode comprovar esta tendência.

0 problema que vem sendo somente agora enfrentado, em relação a esses novos cursos ministrados a distância que explodiram no período 2001-2006, se relaciona à sua qualidade. Apesar do MEC dispor desde 2004 de um sistema de avaliação reguladora, o Sistema Nacional de Avaliação da Educação Superior (Sinaes), somente agora, em 2008, ele está avaliando o trabalho que vem sendo desenvolvido nas centenas de polos de EAD espalhados por todo o país, como mostra essa manchete: "MEC desativa 1.337 centros de educação a distância. Medida atinge quatro instituições que, juntas, concentram $54,7 \%$ dos 760.599 alunos atendidos em todo o país" (WEBER, 2008, p. 5). Espera-se que estas medidas reflitam uma "nova" tendência do MEC no sentido de se preocupar de fato com a expansão quantitativa sem negligenciar a qualidade do ensino; até o momento esta preocupação se refletiu mais nos discursos do que na prática.

Como pôde ser percebido na análise até agora feita, o período 2001-2006 assistiu a uma mudança de rumos do ensino particular, por iniciativa das próprias IES. Por outro lado, é possivel notar que a ênfase das políticas públicas de expansão voltou-se, nesse mesmo periodo, com muito mais ênfase para o setor público da educação superior, forçando um processo de diferenciação de cursos e modalidades de ensino tanto nas universidades federais como nos centros de educação tecnológica.

No caso das universidades federais, a Universidade Aberta do Brasil é uma das politicas mais incisivas de inserção da EAD na educação superior, como expansão, caracterizada no discurso oficial com estratégia de democratização do ensino. 0 Programa, iniciado em 2006, envolve hoje 74 instituições (WEBER, 2008), dispõe de 562 polos espalhados por todo o pais e oferece 67 mil vagas. A preocupação do MEC em institucionalizar este Programa no âmbito federal tem trazido como consequência benéfica, o desenvolvimento de indicadores de qualidade para avaliação desses cursos, tanto na esfera pública como na privada.

Entretanto, a tendência dessa modalidade de ensino é de crescer não somente em termos de número de cursos de graduação - bacharelados, licenciaturas e, principalmente cursos superiores de tecnologia - como também de disciplinas inseridas, no limite de $20 \%$, nos cursos regulares já existentes, conforme Portaria no. 4.059, de 10 de dezembro de 2004 (BRASIL, 2004b). Este "nicho" de diferenciação intracurso tende a se ampliar nos próximos anos sem que o MEC se tenha preocupado, ainda, em avaliar as iniciativas já em curso.

Ensaio: aval. pol. públ. Educ., Rio de Janeiro, v. 17, n. 62, p. 55-86, jan./mar. 2009 
Finalmente, é importante destacar uma das principais prioridades do MEC em termos de políticas públicas para o ensino superior: os cursos superiores de tecnologia. Considerados como cursos de graduação, no mesmo nivel dos bacharelados e licenciaturas, eles garantem, assim, a continuidade dos estudos em pós-graduação lato sensu (especialização) e stricto sensu (mestrado e doutorado). Esta prioridade tem-se traduzido em uma série de medidas já aprovadas - edição em 2006 de um Catálogo nacional dos Cursos Superiores de Tecnologia - ou documentos em vias de aprovação - Projeto de criação dos institutos federais de educação, ciência e tecnologia de 2008 e Princípios norteadores das engenharias nos institutos federais, elaborado em outubro de 2008. Segundo notícia publicada no site do MEC:

Alguns especialistas da área educacional apostam que, no futuro próximo, todos os cursos de graduação terão de um a três anos, no máximo, de forma que o indivíduo inicie seu processo profissional o quanto antes, mantendo vida estudantil paralela à vida profissional. (BRASIL, 2008).

Segundo outros especialistas, no entanto, esta tendência de encurtamento (e consequente aligeiramento) da formação superior e sua vinculação imediatista ao mercado de trabalho representa um perigo para o sistema de educação superior, visto por Sguissardi (2004) como o lócus de construção e socialização do conhecimento e de formação do cidadão crítico.

Resta acompanhar atentamente estas tendências, organizando uma agenda de pesquisas com vistas à avaliação do impacto dessas políticas no sistema de educação superior.

\section{Referências}

BOCCHETI, P. Das escolas de ofício no Brasil ao projeto CEFET. In: MARKERT, W. (Org.). Formação profissional no Brasil. Rio de Janeiro: Paratodos, 1997.

BRASIL. Decreto $n^{\circ}$. 2.207, de 15 de abril de 1997. Regulamenta para o Sistema federal de Ensino disposições contidas na Lei n. 9.394 de 20/12/1996 e dá outras providências. Leis, Brasilia, DF, 16 abr. 1997a. Disponível em:

<www.planalto.gov.br/ccivil_03/decreto/D2207.htm>. Acesso em: 20 set. 2006.

Decreto $n^{\circ} .2 .306$, de 19 de agosto de 1997. Regulamenta para o sistema federal de ensino as disposições contidas na medida Provisória n. 1.477-39 de 3/8/1997 e artigo da Lei no. 9.394 de 20/12/1996 e dá outras providências. Leis, Brasilia, DF, 20 ago. 1997b. Disponivel em: <www.planalto.gov.br/ccivil_03/decreto/Quadros/1997>. Acesso em: 20 set. 2008.

. Decreto $n^{\circ} .2 .406$ de 27 de novembro de1997. Regulamenta a Lei $n^{\circ} .8 .948$ de 8/12/1994 e dá outras providências. Leis, Brasilia, DF, 28 nov. 1997c. Disponivel em:<www.planalto.gov.br/ccivil_03/decreto/Quadros/1997>. Acesso em: 20 set. 2008.

Ensaio: aval. pol. públ. Educ., Rio de Janeiro, v. 17, n. 62, p. 55-86, jan./mar. 2009 
BRASIL. Decreto n ${ }^{\circ}$. 4.914, de 11 de dezembro de 2003. Dispõe sobre os centros universitários de que trata o art. 11 do Decreto n. 3.860 de 0/7/2001 e dá outras providências. Diário Oficial [da República Federativa do Brasil], Brasília, DF, 12 dez. 2003. Número extra, Seção 1, p. 50.

Decreto $n^{\circ} .5 .224$ de 1 de outubro de 2004. Dispõe sobre a organização dos centros federais de educação tecnológica e dá outras providências. Decreto, Brasilia, DF, 4 out. 2004a. Disponivel em: <www.planalto.gov.br/ccivil_03/ decreto/_Ato2004-2006/2004/Decreto/_quadro.htm>. Acesso em: 20 set. 2008.

Decreto no 5.622 de 19 de dezembro de 2005. Regulamenta o art. 80 da Lei $n^{\circ}$. 9.394, de 20 de dezembro de 1996, que estabelece as diretrizes e bases da educação nacional. Diário Oficial [da República Federativa do Brasil], Brasília, DF, 20 dez. 2005. Disponivel em: <http://portal.mec.br/seede/arquivo/pdf/ dec_5622.pdf>. Acesso em: 14 fev. 2006.

BRASIL. Decreto n. 5.786, de 24 de maio de 2006. Dispõe sobre os centros universitários e dá outras providências. Diário Oficial [da República Federativa do Brasil], Brasília, DF, 25 maio 2006a. Seção 1.

Lei $n^{\circ}$. 6.545, de 30 de junho de 1978. Dispõe sobre a transformação das escolas Técnicas federais de Minas Gerais, do Paraná e Celso Suckow em centros federais de educação tecnológica e dá outras providências. Leis, Brasília, DF, 4 jul. 1978. Disponivel em: <www.planalto.gov.br/ccivil_03/LEIS/Quadro/19601980.htm>. Acesso em: 28 mar. 2008.

. Lei no. 8.948 de 1994. Dispõe sobre a instituição do Sistema Nacional de Educação Tecnológica e dá outras providências. Leis, Brasilia, DF, 9 dez. 1994. Disponivel em: <http://www.planalto.gov.br/ccivil/leis/L8948.htm>. Acesso em: 20 set. 2008.

. Lei $n^{\circ}$. 9.394, de 20 de dezembro de 1996. Estabelece as diretrizes e bases da educação nacional. Diário Oficial [da República Federativa do Brasil], Brasilia, DF, ano 134, n. 248, p. 27.833-27.841, 23 dez. 1996.

. Lei $n^{0} .11 .096$, de 13 de janeiro de 2005. Institui o Programa Universidade para Todos - ProUni, regula a doação de entidades beneficentes de assistência social no ensino superior; altera a Lei n. 10.891, de 9 de julho de 2004, e dá outras providências. Diário Oficial [da República Federativa do Brasil], Brasilia, DF, 14 jan. 2005b. Disponivel em: <http://prouni-inscricao.mec.gov.br/ prouni/legislacao.shtm>. Acesso em: 20 set.2006.

. Ministério da Educação. Portaria n. 4.059, de 10 de dezembro de 2004. Diário Oficial [da] República Federativa do Brasil, Brasilia, DF, 13 dez. 2004b. Seção 1, p. 34.

Ensaio: aval. pol. públ. Educ., Rio de Janeiro, v. 17, n. 62, p. 55-86, jan./mar. 2009 
Expansão, privatização e diferenciação da educação superior

BRASIL. Ministério da Educação. Universidade Aberta do Brasil. 2006b. Disponivel em: <www.uab.mec.gov.br>. Acesso em: 11 mar. 2006.

CAMPELLO. A. M.. "Cefetização" das Escolas Técnicas Federais: projetos em disputa. Revista Tecnologia e Cultura, Rio de Janeiro, CEFET/RJ, Ano 8, n. 8, p. 34-44. jan./jun. 2006.

CARVALHO, C. H. de A. Política para o ensino superior no Brasil (1995-2008). Ruptura e continuidade nas relações entre público e privado. In: SILVA, J. R. S. Jr.; OLIVEIRA, J. F.; MANCEBO, D. (Orgs.) Reforma universitária: dimensões e perspectivas. Campinas: Alínea, 2006. p. 125-139.

CATANI, A. M.; HEY, A. P.;GILIOLI, R. S. P. ProUni: Democratização do acesso ás instituições de ensino superior? Educar em Revista, Curitiba, n. 28, p.125-140, jul. /dez. 2006.

CONSELHO NACIONAL DE EDUCAÇÃO (Brasil). Parecer CNE/CP 29, de 3 de dezembro de 2002. Diretrizes curriculares nacionais gerais para a organização e $O$ funcionamento dos cursos superiores de tecnologia. Brasília, DF, 13 dez. 2002. Disponivel em: <http://portal.mec.gov.br/cne/arquivos/pdf/cp.29.pdf>. Acesso em: 20 set. 2008.

FÁVERO, M. L. A.; SEGENREICH, S. C. D. Universidades e centros universitários pós LDB/96: tendências e questões. In: BITAR, M.; OLIVEIRA, J. F.; MOROSINI M. (Org.) Educação superior no Brasil: 10 anos pós-LDB. Brasilia: INEP, 2008.

INEP. Censo da educação superior. sinopse estatística do ensino superior 1997. Brasilia, DF, 1999. Disponivel em: <www.inep.gov.br/superior/censosuperior/ sinopse>. Acesso em: 12 mar. 2008.

. Censo da educação superior. sinopse estatística do ensino superior 2001. Brasilia, DF, 2002. Disponivel em: <www.inep.gov.br/superior/censosuperior/ sinopse>. Acesso em: 12 mar. 2006.

Censo da educação superior. sinopse estatística da educação superior 2006. Brasilia, DF, 2007. Disponivel em: <www.inep.gov.br/superior/ censosuperior/sinopse> . Acesso em: 12 mar. 2008.

. Plano Nacional de Educação - PNE. Brasília, 2001.

JUVENTUDE LIBERTÁRIA DA RESISTÊNCIA POPULAR. ProUni. São Paulo, [2008?]. Disponivel em: <http://www.juli-rp.org/?page=6>. Acesso em: 22 abr. 2009.

Ensaio: aval. pol. públ. Educ., Rio de Janeiro, v. 17, n. 62, p. 55-86, jan./mar. 2009 
MAIA, C. Guia brasileiro de educação a distância. São Paulo: Esfera, 2002.

MANCEBO, D. Reforma universitária: reflexões sobre a privatização e a mercantilização do conhecimento. Educação e Sociedade,

Campinas, SP, v. 25, n. 88, p. 845-866, out. 2004. Número especial.

OTRANTO, C. R. A reforma da educação superior do governo Lula: Da inspiração à implantação. In: SILVA JÚNIOR, J. R. S.; OLIVEIRA, J. F.; MANCEBO, D. (Org.).

Reforma universitária: dimensões e perspectivas. Campinas: Alínea, 2006.

0 QUE é um curso de tecnologia. Universia, São Paulo, 4 jun. 2004.

Disponivel em: <http:// universia.com.br/matéria/matéria.jsp?id=4261>.

Acesso em: 15 nov. 2008.

RISTOFF, D.; GIOLO, J. Introdução: A educação superior no Brasil: panorama geral. In: ___ i_. (Org.). Educação superior brasileira 1991- 2004. Brasilia, DF: INEP, 2006.

SEGENREICH, S. C. D. Relação ensino de graduação e pesquisa: políticas públicas e realidades institucionais. In: SGUISSARDI, V.; SILVA JR, J. R. (Org.). Educação superior. análise e perspectivas. São Paulo: Xamã, 2001.

SEGENREICH, S. C. D. et al. A educação superior no Estado do Rio de Janeiro: 1991 - 2004. In: RISTOFF, D.; GIOLO, J. (Org.). Educação superior brasileira 1991- 2004. Brasilia, DF: INEP, 2006.

SGUISSARDI, V. A universidade neoprofissional, heterônoma e competitiva. In: MANCEBO, D.; FAVERO, M. L. A. (Org.). Universidade: políticas, avaliação e trabalho docente. São Paulo: Cortez, 2004.

SILVA, E. B. Centros universitários: aspectos legais, pedagógicos e administrativos. Estudo, Brasília, ano 15, n. 20, p. 9-18, ago. 1997.

SILVA JUNIOR, J. R. Reformas do Estado, da educação superior e as políticas públicas para formação de professores a distância: implicações políticas e teóricas. In: REUNIÃ̂ ANUAL DA ANPED, 25., 2002, Caxambu. Trabalhos apresentados... Caxambu, MG, 2002.

VIANNEY, J.; TORRES, P.; SILVA, E. A Universidade virtual no Brasil: os números do ensino superior a distância no país em 2002. Santa Catarina: UNISUL/IESALC, 2003. Disponivel em: <www.virtual.unisul.br> . Acesso em: 2 mar. 2003.

WEBER, D. MEC desativa 1.337 centos de educação a distância. O G/obo, Rio de Janeiro, p.15, 18 nov. 2008.

Recebido em: 08/01/2009

Aceito para publicação em: 26/03/2009

Ensaio: aval. pol. públ. Educ., Rio de Janeiro, v. 17, n. 62, p. 55-86, jan./mar. 2009 